Article

\title{
Ground Stability Analysis in Non-Open-Cut Tunneling Method Using Small-Diameter Steel Pipe Piles
}

\author{
Jonguk Kim ${ }^{1}$, Jung-joo Kim ${ }^{2}$, Hafeezur Rehman ${ }^{3}$ and Hankyu Yoo ${ }^{4, *}$ \\ 1 Department of Urban Infrastructure Research, Seoul Institute of Technology, 7F 37 Maebongsan-ro, Mapo-gu, \\ Seoul 03909, Korea; jonguk@sit.re.kr \\ 2 Structural and Seismic Technology Group, KEPCO Research Institute, 105 Munji-ro, Yuseong-gu, \\ Daejeon 34056, Korea; jungjoo.kim@kepco.co.kr \\ 3 Department of Mining Engineering, Baluchistan University of Information Technology Engineering and \\ Management Sciences (BUITEMS), Quetta 87300, Pakistan; hafeezur.rehman@buitms.edu.pk \\ 4 Department of Civil and Environmental Engineering, Hanyang University, 55 Hanyangdaehak-ro, \\ Sangnok-gu, Ansan 15588, Korea \\ * Correspondence: hankyu@hanyang.ac.kr; Tel.: +82-31-400-5147
}

Received: 12 September 2020; Accepted: 30 September 2020; Published: 2 October 2020

check for updates

\begin{abstract}
The non-open-cut method is used for constructing tunnels under existing roads without blocking traffic. Various non-open-cut methods use pipe roofs made of medium- and large-diameter steel pipe piles. However, the risk of ground settlement or heave is involved during the application of such piles. Therefore, research is conducted through model tests and numerical analysis on the non-open-cut method to investigate these problems using small-diameter piles. The progress of tunnel construction is divided into two repetitive steps. The first step (Stage 1) involves pulling back the pressure panel, and the second step involves propelling the precast structure (Stage 2). The behaviors of the pipe piles and ground displacement are analyzed according to the cover depth, tunnel size, existence and nonexistence of the shoe structure, and progress of tunnel construction. Small-diameter piles reduce the displacement during both stages. With a decrease in cover depth, the stress acting on the pile decreases during Stage 1 and increases during Stage 2. The presence of the shoe structure reduces the stress on the pile during both stages. The ground behavior based on the construction progress indicates that the ground settlement increases during Stage 1; however, no correlation is observed during Stage 2 at low depth.
\end{abstract}

Keywords: underground multilevel crossing road construction method; non-open-cut method; shallow tunnel; small-diameter steel pipe piles; forepoling

\section{Introduction}

Owing to an increase in the urban population, traffic has become a major issue in the megacities of the world. To overcome this issue, road networks in large cities are becoming increasingly complex. The more complex a road network becomes, the more often a new road is constructed under the existing road. When such a construction has to be undertaken without interrupting the traffic, the non-open-cut method of tunneling is used. Several non-open-cut methods, such as the pipe roof structure (PRS), tubular roof construction method (TRcM), new tubular roof (NTR), roof panel shield (RPS), and front jacking methods, are used for constructing tunnels under existing roads.

In the PRS, TRcM, NTR, and RPS methods, the tunnel is constructed by placing concrete under the roof that is formed by each method of arranging the steel pipes. During tunnel construction using medium- and large-sized ( $800-2800 \mathrm{~mm}$ ) steel pipes, ground settlement or heave may occur during 
the process of pressing steel pipes or digging up soil inside steel pipes. Front jacking is a method of installing precast structures by towing them on the other side to a certain location after installing the pipe roof. In this method, a completely formed concrete box is used, and the tunnel structure is comparatively more stable than other non-open-cut methods. However, settlement is possible because of the gap between the structure and the pipe roof [1].

As the ultimate goal of tunnel construction under existing roads is safety as well as minimum displacement during the construction, the non-open-cut method of tunneling using small-diameter steel pipe piles (ø $114 \mathrm{~mm}, 6 \mathrm{~T}$ ) to avoid problem that using medium- and large-sized is described in this paper.

In this study, the steps of construction, which are impacted by the stability of the piles, were simplified and divided into two stages: model testing and numerical modeling. The first step of construction (Stage 1) involves pulling back the pressure panel, and the second step involves propelling the precast structure (Stage 2). A model test was conducted to analyze the tendency of the piles to remain stable based on the cover depth, tunnel size, and existence of shoe structure. A numerical analysis was conducted to verify the model test results and analyze the impact of varying the relative location between the pile and the tunnel face on the construction of the tunnel. Abaqus 2019 was used for the numerical analysis because it is capable of considering the interaction between the ground and the tunnel during large deformation analysis [2].

\section{Problems with Existing Non-Open-Cut Methods}

During tunnel construction under existing operational roads using the non-open-cut method, the allowable value for ground settlement and heave to ensure the safety of road or railway traffic is $13 \mathrm{~mm}$ [3]. If the value of ground settlement or heave exceeds the allowable value, construction should be stopped and recovery plans and measures should be considered to prevent recurrence. Pavement damage, such as cracks, ground settlement, and heave could occur at each construction step in the non-open-cut method, as detailed in Table 1 [3]. The cases of blocking off traffic owing to ground settlement or heave during tunnel construction using the non-open-cut method along various expressways in the Republic of Korea are presented in Table 2 [3,4].

Table 1. Type of pavement damage occurrence possible at each step of construction of the underground multilevel crossing road under the highway, using the non-open-cut method.

\begin{tabular}{ccc}
\hline Construction Step & Cause of Occurrence & Damage Type \\
\hline installing temporary support & $\begin{array}{c}\text { relaxation of face of slope } \\
\text { installing steel pipe }\end{array}$ & $\begin{array}{c}\text { crack and settlement of shoulder } \\
\text { grouting }\end{array}$ \\
$\begin{array}{c}\text { excessive grouting injection } \\
\text { pressure } \\
\text { excavation of lower part } \\
\text { removing temporary support }\end{array}$ & $\begin{array}{c}\text { deformation of pipe roof and } \\
\text { settlement of lower part of support } \\
\text { relaxation of face of slope }\end{array}$ & crack and settlement of pavement \\
crack and settlement of pavement \\
\hline
\end{tabular}

Table 2. Case of blocking off traffic urgently during construction in the non-open-cut method.

\begin{tabular}{ccc}
\hline Name of Expressway & Construction Method & Displacement (Damage Type) \\
\hline Gyeongbu & STS (steel tube slab) & $71 \mathrm{~mm}$ (settlement) \\
Youngdong & PRS (pipe roof structure) & $90 \mathrm{~mm}$ (settlement) \\
Youngdong & UPRS (upgrade pipe roof structure) & $76 \mathrm{~mm}$ (heave) \\
Gyeongbu & UPRS & $100 \mathrm{~mm}$ (heave) \\
Gyeongbu & NTR (new tubular roof) & $80 \mathrm{~mm}$ (settlement) \\
\hline
\end{tabular}


Eum et al. [5], analyzed the behavior of the ground during the construction of a railway underground crossing, in which the front jacking and PRS methods were applied. According to the study, $50-60 \%$ of the total displacement occurred during the insertion of medium- and large-diameter steel pipe piles and excavation inside the piles. Shin et al. [6], simulated RPS using three-dimensional numerical analysis, which indicated that one-third of the total displacement occurred during installation of the steel pipe piles during the construction of the pipe roof. Eum et al. [7], analyzed the pattern of settlement at each construction stage at three construction sites using the front jacking method, and, as per their findings, $27-56 \%$ and $44.3 \%$ of the total displacement occurred during the pipe pile insertion step.

\section{Concept of Non-Open-Cut Method Using Small-Diameter Steel Pipe Piles}

The non-open-cut method is used for constructing underground crossings at low depths under existing roads and rail tracks. Most non-open-cut methods use a pipe roof type that inserts mediumand large-diameter steel pipe piles $(800-2800 \mathrm{~mm})$ to construct the roof and excavate inside the piles. As discussed in Section 2, however, settlement or heave of the ground is possible when mediumand large-diameter steel pipe piles are used. Therefore, small-diameter steel pipe piles (Figure 1a, $\varnothing 114 \mathrm{~mm}, 6 \mathrm{~T}$ ) are used for forepoling to minimize the settlement or heave of the ground. In such piles, low-pressure grouting is used to minimize ground disturbance [8]. The front pressure panel (Figure 1b) is developed to prevent the tunnel face from collapsing and the accompanying risks during the use of the non-open-cut method. The front pressure panel consists of several pushing plates and face jacks. The shoe structure, which is made of steel plates, was attached around the front face of the precast structure, and it prevented the collapse of the ground and falling rock (Figure 1c).

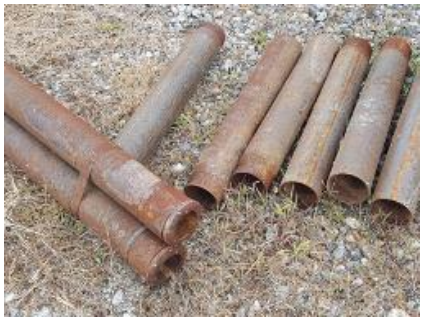

(a)

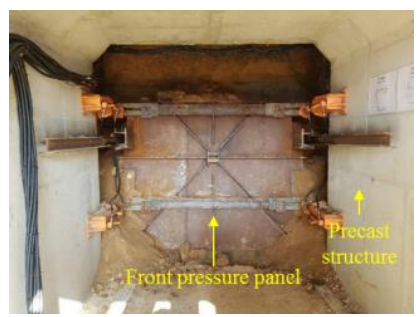

(b)
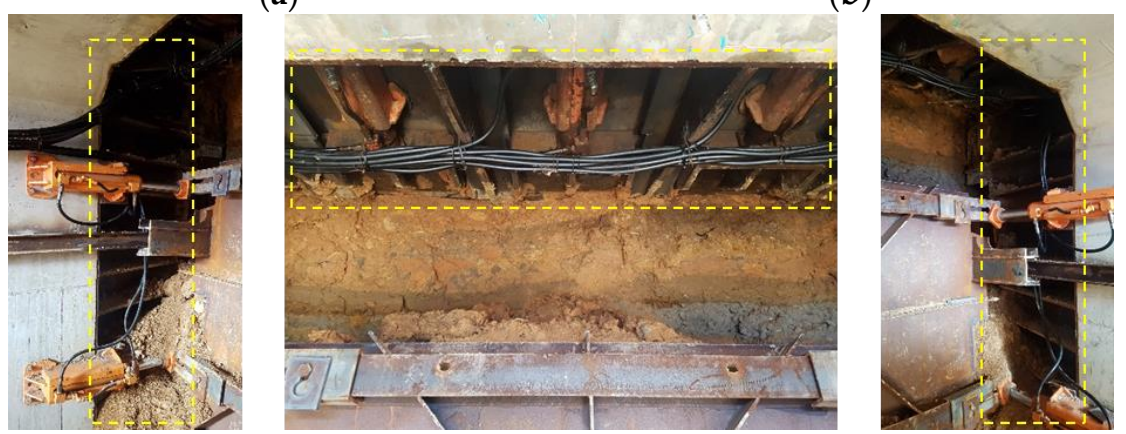

(c)

Figure 1. Actual composition of equipment: (a) small-diameter steel pipe piles. (b) Front pressure panel and precast structure. (c) Shoe structure (left, upper, and right). 
The non-open-cut method used in this study generally follows several construction steps as shown in Figure 2. First, the forepoling is installed using a small steel pipe, and the pressure panel is placed at the tunnel face. Thereafter, the precast structure is propelled forward (Stage 2) and the pressure panel is pulled back (Stage 1). Subsequently, the tunnel face is excavated using an excavator. The tunnel is constructed by repeating these steps.

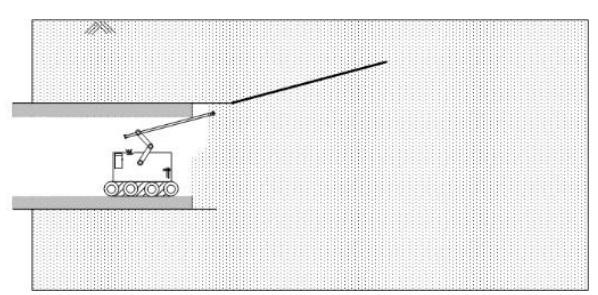

(a)

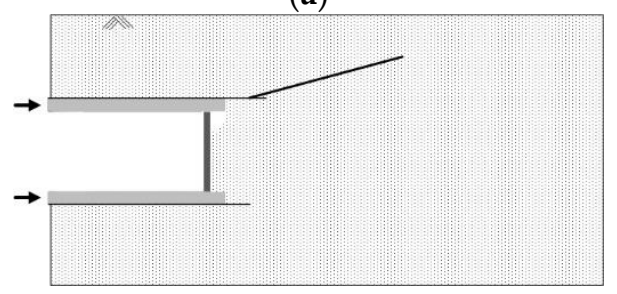

(c)

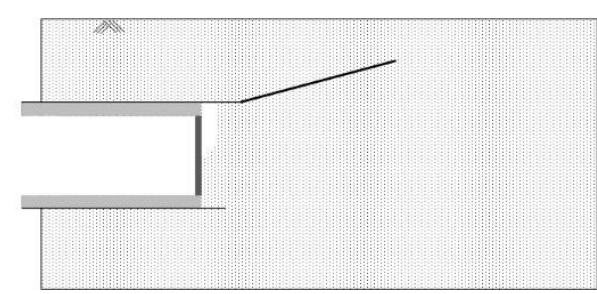

(b)

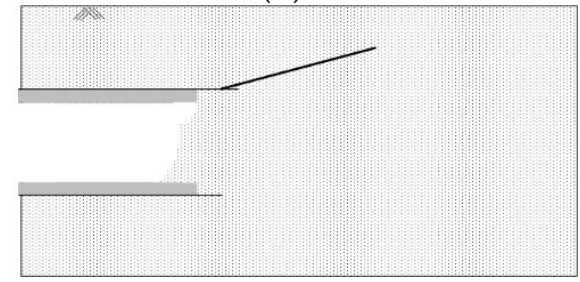

(d)

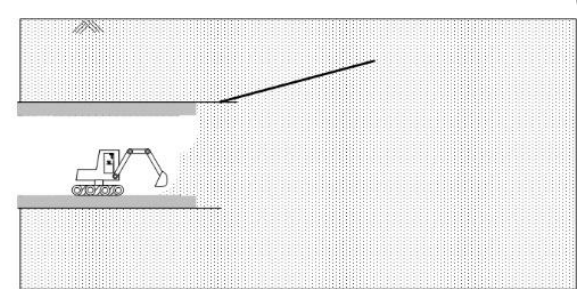

(e)

Figure 2. The step of tunnel construction in the non-open-cut method using small steel pipe piles: (a) installation of the forepoling using small steel pipe piles. (b) Placing the pressure panel at the tunnel face. (c) Propulsion of the precast structure (Stage 2). (d) Pulling back the pressure panel (Stage 1).

(e) Excavation of the tunnel face using excavator.

\section{Analysis of Pile Behavior Based on Model Test}

\subsection{Overview of Model Test}

Two processes affect pipe piles during construction cycles: Stage 1, pulling back the pressure panel; Stage 2, propelling the precast structure forward. During Stage 1, if the ground is weak, the pile might be bent downward because of the collapse of the tunnel face. During Stage 2, the pipe might be lifted and bent upwards. Therefore, 36 model tests were performed to confirm the behavior of the piles during these two processes; their details are summarized in Table 3. To consider the tunnel size and their excavation sequence effect, three types of tests were conducted, as illustrated in Figure 3. The basic height of a one-level tunnel model is $125 \mathrm{~mm}$, which is minimized to $1 / 20$ th of the actual tunnel height of $2.5 \mathrm{~m}$. The height of the two-level tunnel model is $250 \mathrm{~mm}$. Figure 4 depicts the construction of a two-level tunnel. In this case, the large tunnel face is divided into two levels to prevent large-scale accidents of ground settlement that occur during Stage 1. As the non-open-cut method is generally used for the construction of underground crossings at existing roads at low cover depths, the cover depths in the experiments in this study were determined to be $1.5,2$, and $3.5 \mathrm{~m}$, and the behavior of the pile was analyzed at each cover depth. 
Table 3. Test scenarios of model tests.

\begin{tabular}{|c|c|c|c|c|}
\hline $\begin{array}{c}\text { Shape of } \\
\text { Tunnel } \\
\text { Structure }\end{array}$ & Height and Level & $\begin{array}{l}\text { Construction } \\
\text { Cycle }\end{array}$ & Shoe Structure & Cover Depth (mm) \\
\hline \multirow[t]{2}{*}{ Type 1} & \multirow{2}{*}{ one level } & $\begin{array}{l}\text { propelling precast } \\
\text { structure }\end{array}$ & $\begin{array}{l}\text { with or without } \\
\text { shoe structure }\end{array}$ & $175 / 125 / 75$ \\
\hline & & $\begin{array}{l}\text { pulling back } \\
\text { pressure panel }\end{array}$ & $\begin{array}{l}\text { with or without } \\
\text { shoe structure }\end{array}$ & $175 / 125 / 75$ \\
\hline \multirow[t]{2}{*}{ Type 2} & \multirow{2}{*}{$\begin{array}{c}\text { one level; same } \\
\text { height as two levels }\end{array}$} & $\begin{array}{l}\text { propelling precast } \\
\text { structure }\end{array}$ & $\begin{array}{l}\text { with or without } \\
\text { shoe structure }\end{array}$ & $175 / 125 / 75$ \\
\hline & & $\begin{array}{l}\text { pulling back } \\
\text { pressure panel }\end{array}$ & $\begin{array}{l}\text { with or without } \\
\text { shoe structure }\end{array}$ & $175 / 125 / 75$ \\
\hline \multirow[t]{2}{*}{ Type 3} & \multirow[t]{2}{*}{ two levels } & $\begin{array}{l}\text { propelling precast } \\
\text { structure }\end{array}$ & $\begin{array}{l}\text { with or without } \\
\text { shoe structure }\end{array}$ & $175 / 125 / 75$ \\
\hline & & $\begin{array}{l}\text { pulling back } \\
\text { pressure panel }\end{array}$ & $\begin{array}{l}\text { with or without } \\
\text { shoe structure }\end{array}$ & $175 / 125 / 75$ \\
\hline
\end{tabular}

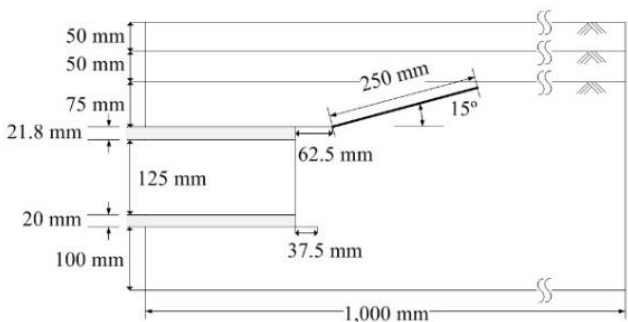

(a)

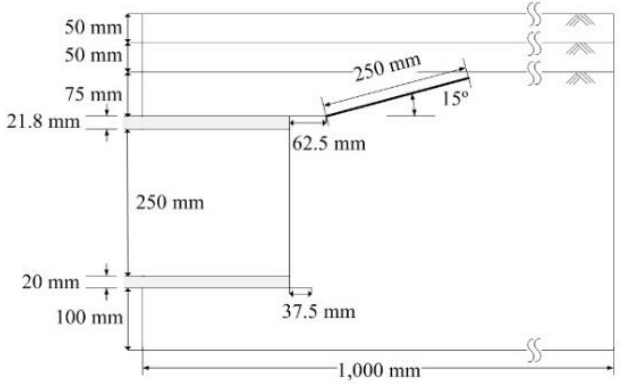

(b)

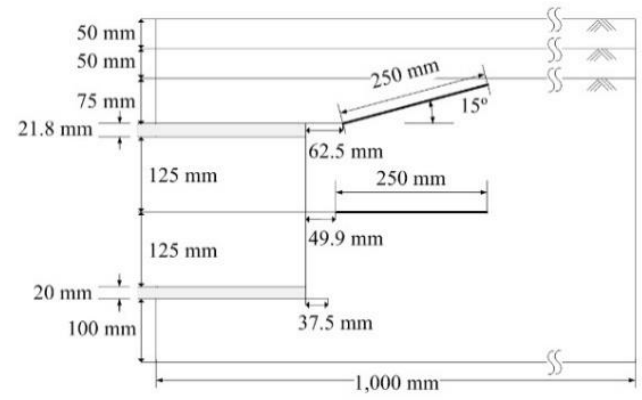

(c)

Figure 3. Test cases for shape of tunnel structure: (a) Type 1-one level. (b) Type 2-one level but with same height as two levels. (c) Type 3-two levels.

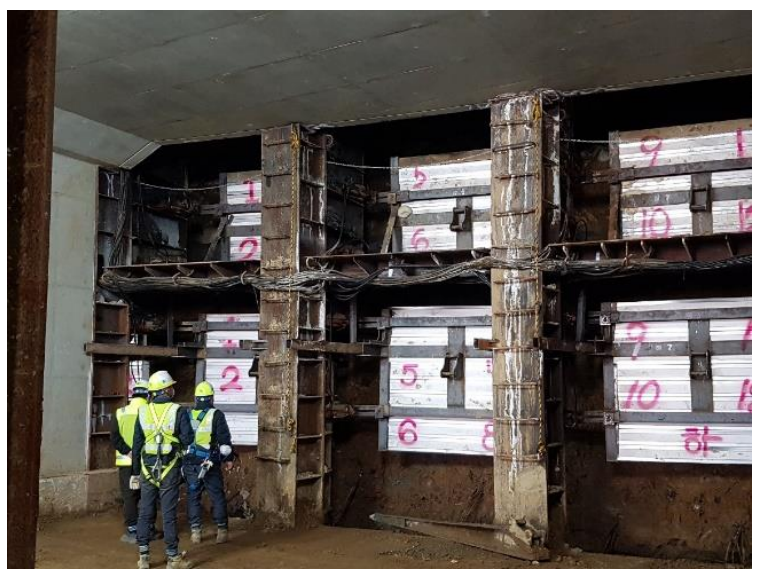

Figure 4. Two levels under construction tunnel. 
The experimental equipment for the model tests was designed, as displayed in Figure 5, to analyze the behavior of the pile. The size of the soil box was $1000 \mathrm{~mm} \times 900 \mathrm{~mm} \times 700 \mathrm{~mm}$, and it was designed to be large enough to prevent any effects on the results of the model test. To analyze the behavior of the pile during the three construction types, the experimental equipment was designed such that it can propel and pull back the precast structure, upper pressure panel, and lower pressure panel using three motors. As displayed in Figure 5c, the shoe structure is connected to the precast structure using bolts so that it remains removable. It was also designed to enable the behavior of the pile and ground to be checked based on the existence of a shoe structure.

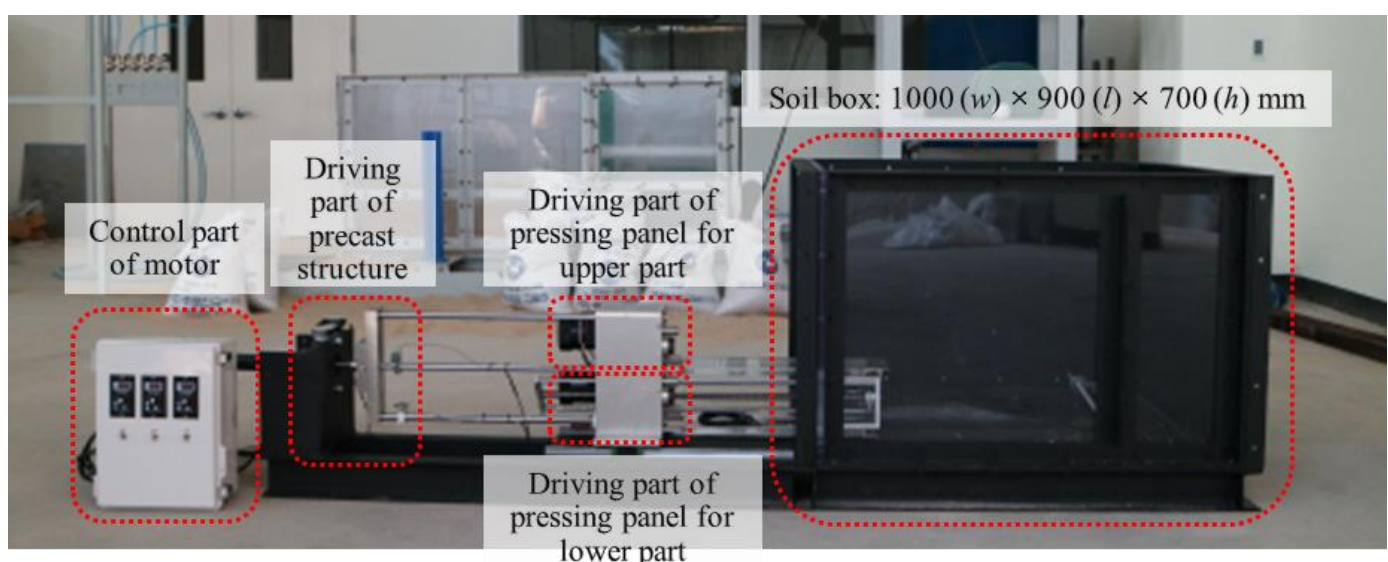

(a)

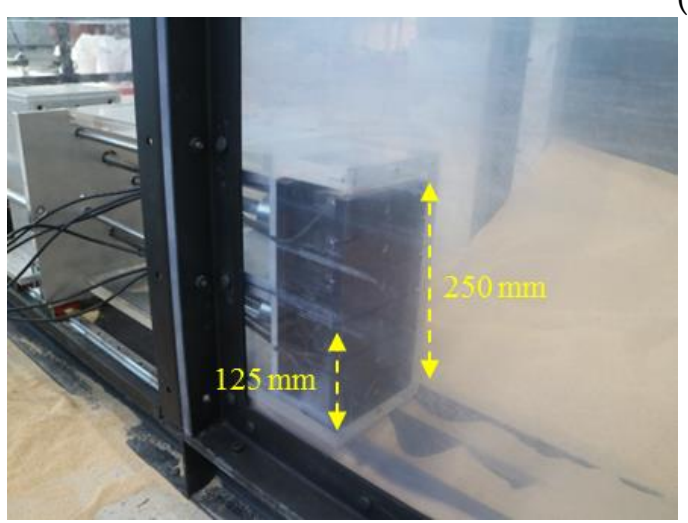

(b)

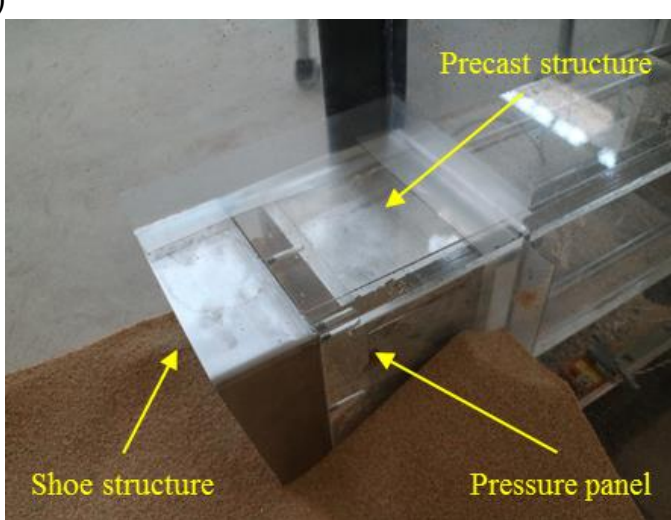

(c)

Figure 5. Experimental equipment for model test: (a) front view. (b) Tunnel model for two levels.

(c) Joint part of precast and shoe structure.

To determine the specifications of the pile, the properties of the ground for construction were determined first. The non-open-cut method is generally used for construction under the condition of weak ground stiffness, such as on weathered soil. In this study, the properties of the ground were determined, as presented in Table 4, by averaging the properties of the ground acquired from other studies that have applied the non-open-cut method [9-12].

Table 4. Representative ground properties applied using the non-open-cut method.

\begin{tabular}{ccccc}
\hline Density & $\begin{array}{c}\text { Deformation } \\
\text { Modulus (kPa) }\end{array}$ & Poisson's Ratio & Friction Angle ( $\left.{ }^{\circ}\right)$ & Cohesion (kPa) \\
\cline { 1 - 3 } $\mathbf{( k N / \mathbf { m } ^ { 3 } )}$ & $30,650.4$ & 0.3 & 29.6 & 6 \\
\hline 18.46 & & & \\
\hline
\end{tabular}


The specification of the pile was determined based on the method suggested by Kim [13]. Several conditions such as the installation angle of the piles, optimal length of the piles, and length of the overlapping construction were calculated using the ground properties; the details are presented in Table 5. During the model test, only one pile was used, and the length of the pile was $25 \mathrm{~cm}$, which is equal to $1 / 20$ th of the actual size.

Table 5. Pile properties.

\begin{tabular}{ccccc}
\hline \multirow{2}{*}{$\begin{array}{c}\text { Assumed } \\
\text { Condition }\end{array}$} & $\begin{array}{c}\text { Installation Angle } \\
\left({ }^{\circ}\right)\end{array}$ & $\begin{array}{c}\text { Lateral Interval } \\
(\mathbf{m})\end{array}$ & $\begin{array}{c}\text { Diameter of } \\
\text { Grouting Bulb }(\mathbf{m})\end{array}$ & FS \\
\cline { 2 - 5 } & 15 & 0.6 & 1.0 & 2.0 \\
\hline $\begin{array}{c}\text { Result of } \\
\text { Calculation }\end{array}$ & \multicolumn{2}{c}{ Length of Pile (m) } & Length of Overlapping Construction (m) \\
\cline { 2 - 5 }
\end{tabular}

The behavior of the pile was observed by sticking eight strain gauges at equal distances on a polycarbonate pile (Figure 6a and Table 6). The physical properties of polycarbonate are listed in Table 7. The load cells were stuck on the pressure panel to measure the pressure of the tunnel face (Figure 6b). A strain gauge (KFGS-5-120-C1-11L5M2R, Kyowa) was used to measure the strain in one direction. A load cell (DBBP-20, Bongshin) was used, and the maximum measuring value of this model was $196 \mathrm{~N}$.

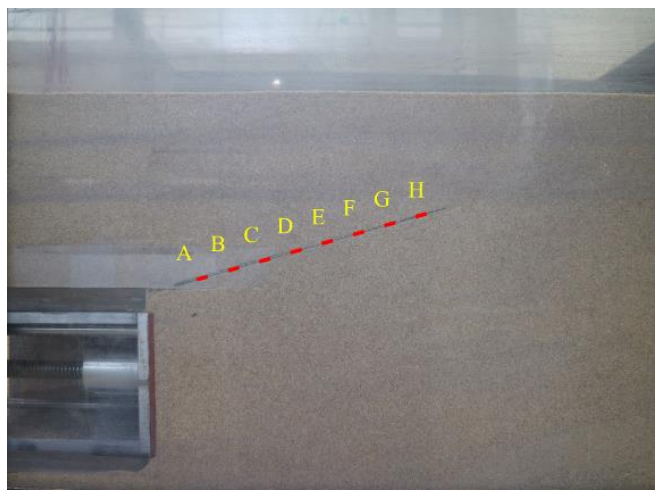

(a)

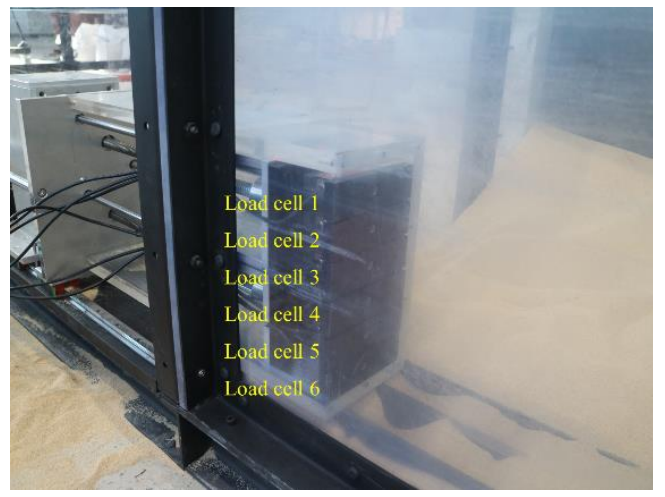

(b)

Figure 6. Measuring system: (a) strain gauges on pile. (b) Load cell on pressure panel.

Table 6. Point on pile of each strain gauge.

\begin{tabular}{cccccc}
\hline Strain Gauge & Head Point & A & B & C & D \\
\hline point on pile $(\mathrm{mm})$ & 0 & 27.78 & 55.56 & 83.33 & 111.11 \\
\hline Strain Gauge & E & F & G & H & End Point \\
\hline point on pile $(\mathrm{mm})$ & 138.89 & 166.67 & 194.44 & 222.22 & 250 \\
\hline
\end{tabular}

To compose uniform Jumunjin sand, the ground was set up using the sand curtain method, in which sand is dropped down from a height of $1 \mathrm{~m}$. The physical properties of sand were tested for the model; their properties are presented in Table 7. The relative density of the set-up ground was measured as $84.69 \%$. The minimum and maximum relative densities of the ground were calculated under the JIS 1224 (2009) standard. 
Table 7. Physical properties of Jumunjin sand polycarbonate.

\begin{tabular}{ccc}
\hline Contents & Jumunjin Sand & Polycarbonate \\
\hline specific gravity & 2.681 & 1.19 \\
\hline unit weight per volume $\left(\mathrm{kN} / \mathrm{m}^{3}\right)$ & 15.32 & - \\
\hline water content ratio $(\%)$ & 0.1 & - \\
\hline maximum density $\left(\mathrm{kN} / \mathrm{m}^{3}\right)$ & 15.73 & - \\
\hline minimum density $\left(\mathrm{kN} / \mathrm{m}^{3}\right)$ & 13.35 & - \\
\hline relative density $(\%)$ & 84.69 & - \\
\hline coefficient of uniformity & 1.6 & - \\
\hline coefficient of curvature & 1.0 & - \\
\hline angle of friction $\left({ }^{\circ}\right)$ & 33.8 & 60 \\
\hline cohesion $(\mathrm{kPa})$ & 0.1 & 2000 \\
\hline tensile strength $(\mathrm{MPa})$ & - & - \\
\hline elastic modulus $(\mathrm{MPa})$ & - & - \\
\hline
\end{tabular}

\subsection{Results of Model Test}

To analyze the behavior of the piles, the tendency of the pressure of the tunnel face to vary according to Stage 1 was analyzed first. It was considered as the point of occurrence of destruction when the pressure of the tunnel face was reduced and converged by pulling back the pressure panel at a speed of $2 \mathrm{~mm} / \mathrm{min}$. The experiment led to release of stress at the same moment as the movement of the pressure panel, and there were no appreciable variations in the pressure panel from the point of pulling back the pressure panel by $3 \mathrm{~mm}$ (Figure 7). In the experimental results, the negative values of stress acting on the pressure panel were observed. These values might have been caused by the tensile strength of the load cell owing to the jammed sand between the pressure panel and the wall of the precast structure during Stage 1. However, a tendency toward reduction in pressure was observed.

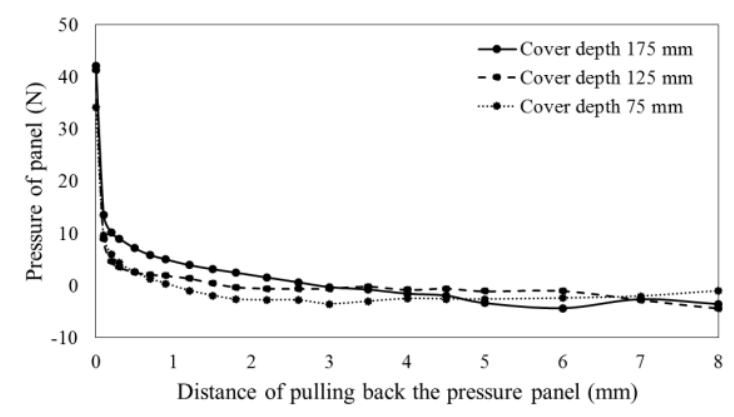

Figure 7. Pressure of panel according to distance during Stage 1.

Figures 8 and 9 show the example of the stresses acting on the piles based on the experiment progresses at each measurement point on the piles in test case type 1 at cover depth of $125 \mathrm{~mm}$. Figure 10 shows a graph of only the maximum or minimum values measured when a single test case was performed. The stress acting on the pile during Stage 1 according to cover depth in the model test is presented in Figure 10a. As the cover depth increased, the stresses acting on the piles increased as the ground load increased. The shoe structure reduced the stresses acting on the piles. In test case type 2, the stresses acting on the piles were larger than those in test case type 1 because the loss of ground volume was larger than that in test case type 1 (Figure 3). The stresses acting on the piles during Stage 2 according to the cover depth in the model test are depicted in Figure 10b. As the cover depth decreased, the piles were bent more owing to the small overburden load, which counters the force of heave. The stresses acting on the piles generally increased. The shoe structure reduced the 
stresses acting on the piles. In test case type 2, the stresses acting on the piles were smaller than those in test case type 1 because the lower precast structure was further away from the ground surface. Type 3 experiments were conducted to determine the behavior of the piles located in the middle of two levels, into which the tunnel face was divided. However, no significant value was measured for the pile located in the middle because the pile at the top supported all the upper ground load.

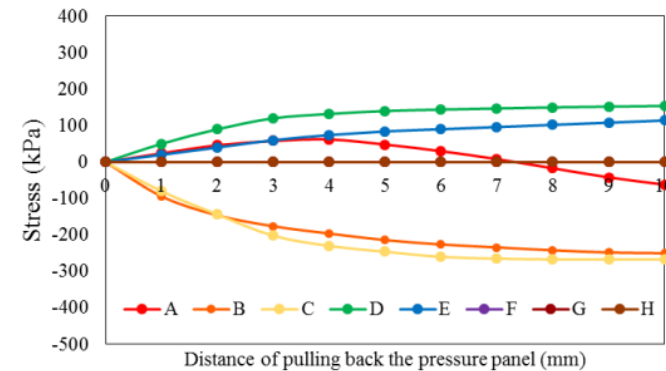

(a)

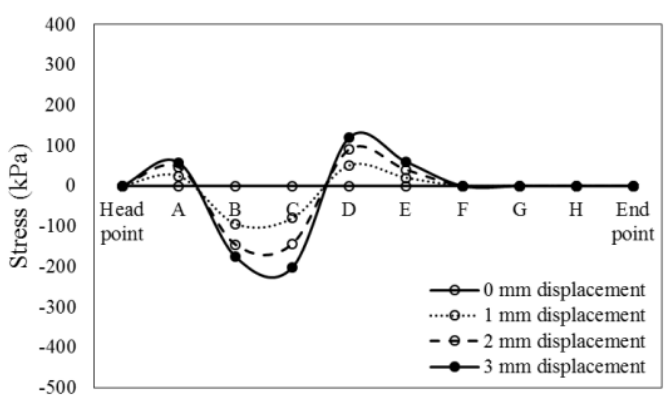

(b)

Figure 8. Variation in stress acting on piles in case of type 1 with shoe structure at cover depth of $125 \mathrm{~mm}$ during Stage 1: (a) based on strain gauges. (b) Based on distance of pulling back the pressure panel.

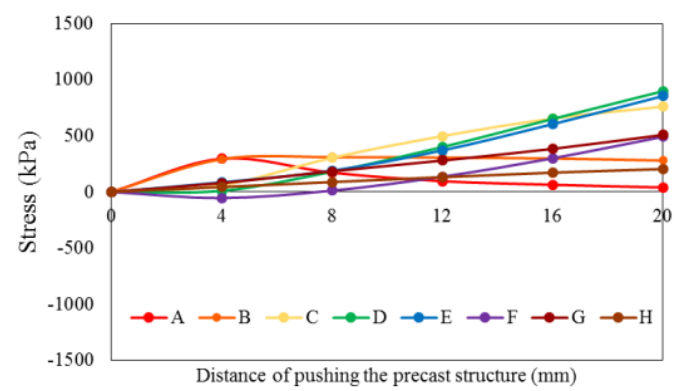

(a)

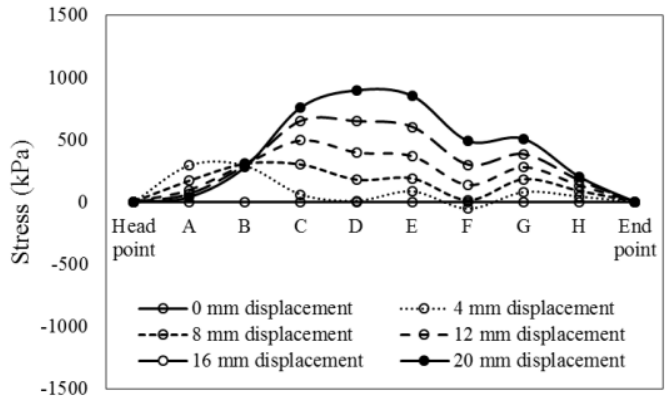

(b)

Figure 9. Variation in stress acting on piles in case of type 1 with shoe structure at cover depth of $125 \mathrm{~mm}$ during Stage 2: (a) based on strain gauges. (b) Based on distance of propelling the precast structure.

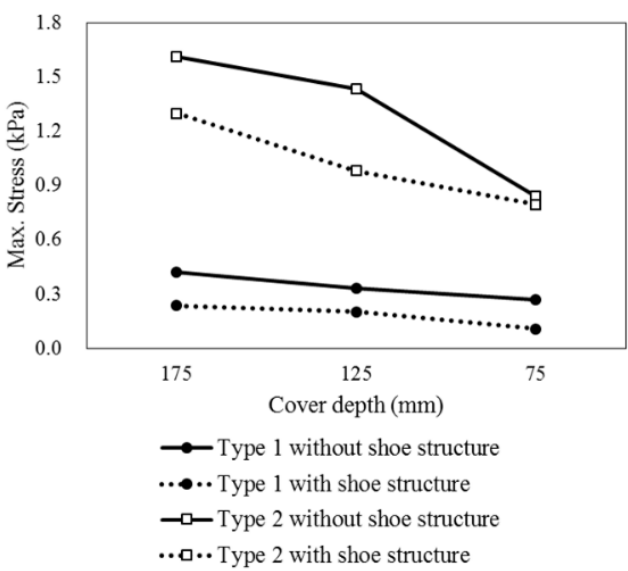

(a)

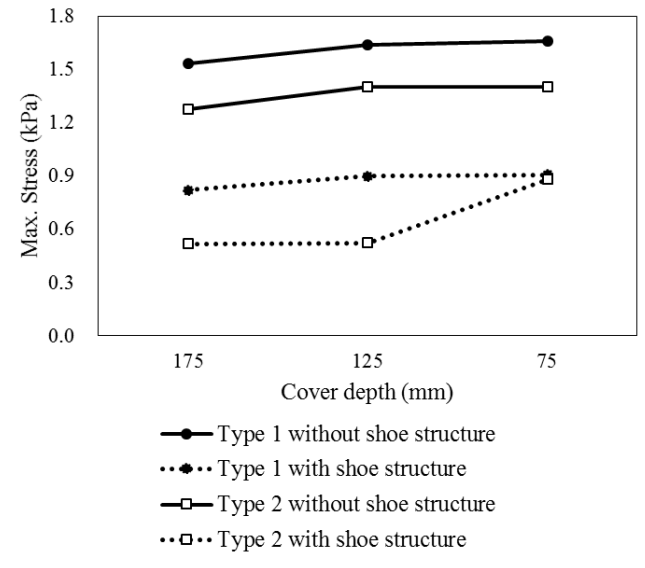

(b)

Figure 10. Maximum stress acting on piles during two stages according to cover depth: (a) during Stage 1. (b) During Stage 2. 


\section{Numerical Analysis of Pile Behavior under Conditions of Actual Tunnel Size}

\subsection{Numerical Modeling Method}

The behaviors of the piles were analyzed by numerically modeling the actual tunnel size. The weathered soil is too weak to endure the collapse of the tunnel face; thus, it can flow down. Therefore, Abaqus 2019, which enables the analysis of large deformations, was used for the numerical analysis in this study. The nonlinear geometry tool of Abaqus was used for the analysis of large deformations, and an explicit analysis was conducted to improve the convergence of the analysis. The Abaqus interaction tool allows the friction coefficient and penetration to be set under the properties of each object. In this study, for the convergence of the numerical analysis, the friction coefficient between the precast structure and the ground was set as zero. The precast structure was set as the master surface and the ground was set as the slave surface. The Mohr-Coulomb model was used for the ground of constitutive model and ground properties is shown in Table 4. Two-dimensional finite element analysis under the plane strain condition was performed using the CPE4R mesh, considering the reduced integration elements option. This option is more suitable for large deformation analysis [14]. The range of analysis is depicted in Figure 11, considering the installed pile specifications listed in Table 5 .

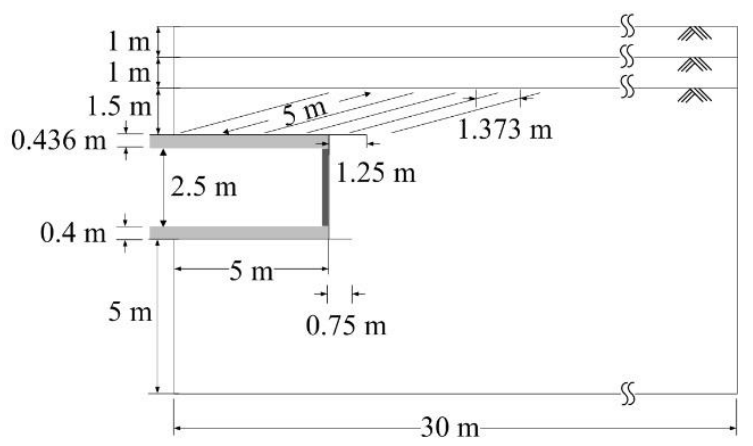

Figure 11. Specification of modeling range.

As mentioned above, the tunnel is constructed by repeating the processes of stages 1 and 2, and this repeated process is referred to as one cycle. The piles are installed continually between stages 1 and 2; accordingly, the stresses on the piles keep varying. The distance through which the precast structure is propelled in one cycle is $0.4 \mathrm{~m}$. Therefore, the tunnel moves forward by $0.4 \mathrm{~m}$ at the end of each cycle. The distance between the pile and the tunnel during the progress of tunnel construction is depicted in Figure 12. The behaviors of the piles and the ground at cover depths of 1.5, 2.5, and $3.5 \mathrm{~m}$ were analyzed.

In contrast to the procedure followed in static analysis, a time factor should be set for the numerical analysis conducted in explicit analysis; this time factor impacts the result of such numerical analysis. In particular, during construction Stage 1, sufficient time is required to stabilize the ground owing to the collapse of the tunnel face.

The results of numerical analysis for the maximum stress on the pile for each period of analysis during the fifth cycle at a cover depth of $1.5 \mathrm{~m}$, which constitute the most probable cases for ground failure, are presented in Figure 13. The nearest pile from the tunnel face was numbered Pile-1. The piles were named in numerical order according to the distance from the tunnel face. As depicted in Figure 14, the tunnel face starts to collapse by moving the pressure panel away from the tunnel face. From the point of $4.8 \mathrm{~s}$, the ground remain separated from the pressure panel (Figure 14c), but there is still a slight settlement of the ground and variations in the stresses acting on the piles. For this reason, all analyses in this study were conducted for $12 \mathrm{~s}$, which is long enough to minimize the variations in the stresses acting on the piles. 


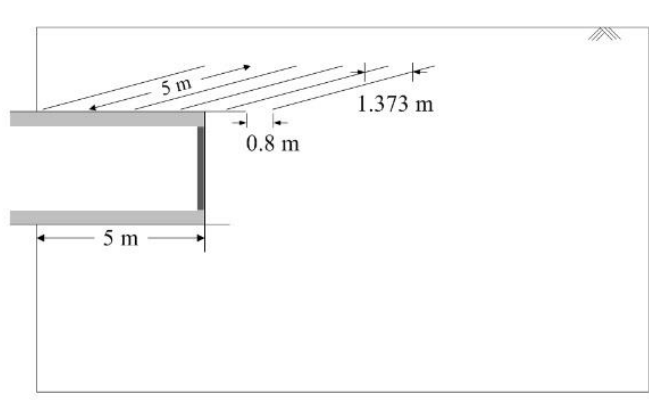

(a)

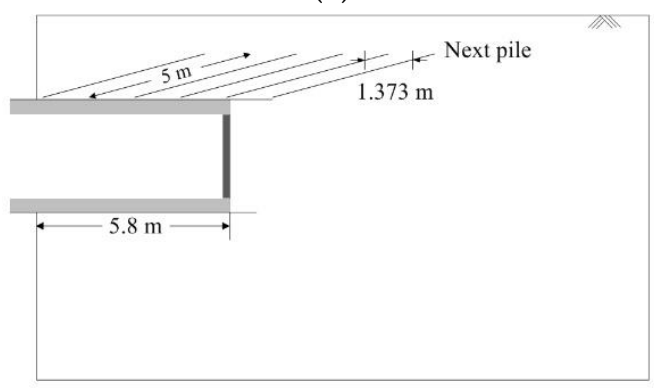

(c)

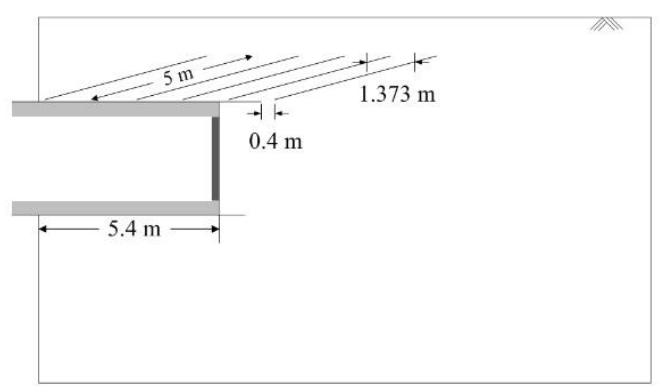

(b)

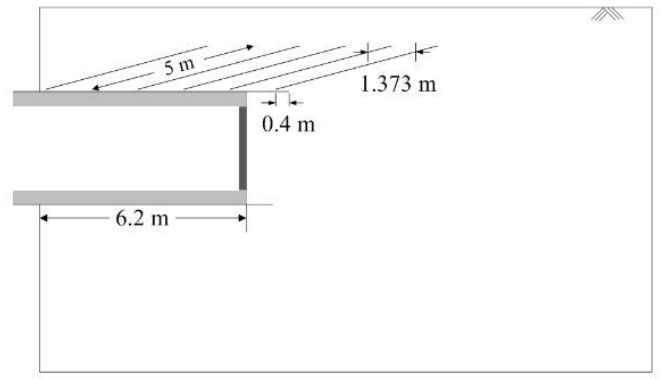

(d)

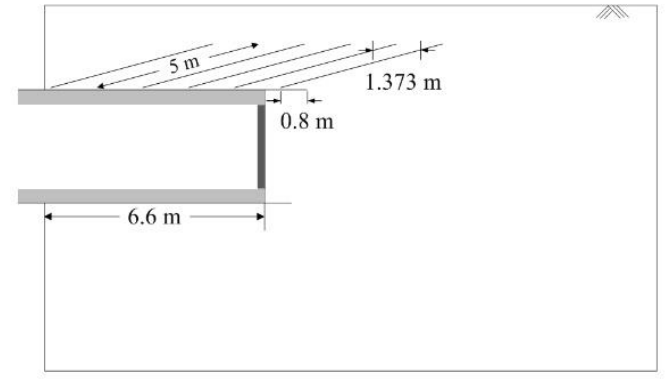

(e)

Figure 12. Location of piles according to progress of construction: (a) initial state of first cycle. (b) Initial state of second cycle. (c) Initial state of third cycle. (d) Initial state of fourth cycle. (e) Initial state of fifth cycle.

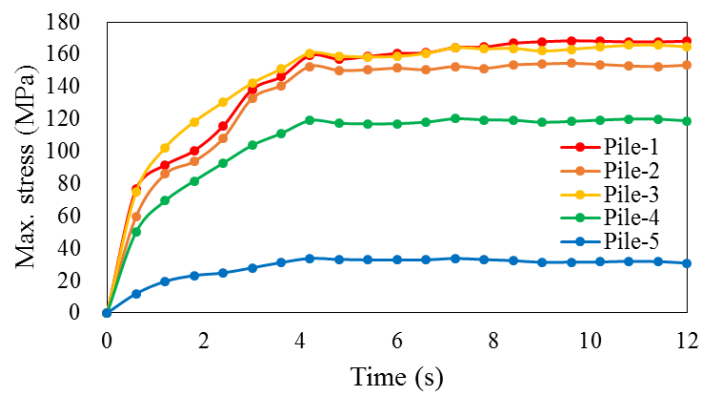

Figure 13. Variation in stress acting on piles according to time during the fifth cycle at cover depth of $1.5 \mathrm{~m}$. 


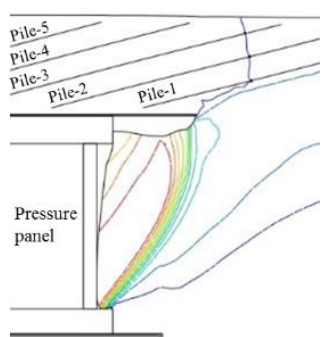

(a)

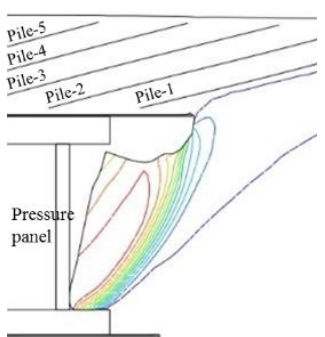

(b)

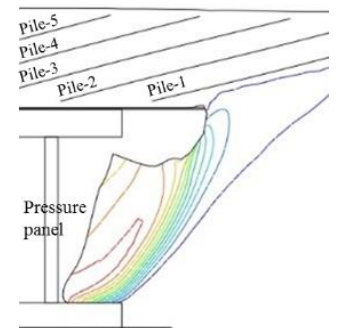

(c)

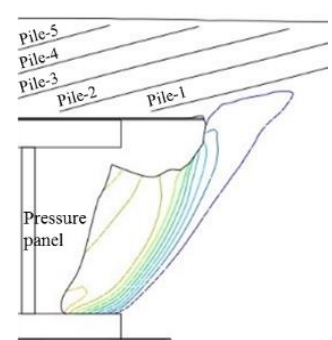

(d)

Figure 14. Behavior of tunnel face with respect to time: (a) $1.2 \mathrm{~s}$, (b) $3 \mathrm{~s}$, (c) $4.8 \mathrm{~s}$, (d) $6 \mathrm{~s}$.

\subsection{Results of Numerical Analysis for Stage 1 of Each Construction Cycle}

The behavior of the ground during Stage 1 of each construction cycle according to the existence or nonexistence of a pile, each cover depth, and each cycle is depicted in Figure 15 through contouring. Whereas the displacement of the ground occurred up to the surface of the ground when there was no pile, the settlement of the ground was restrained during any cycle when the pile was installed.

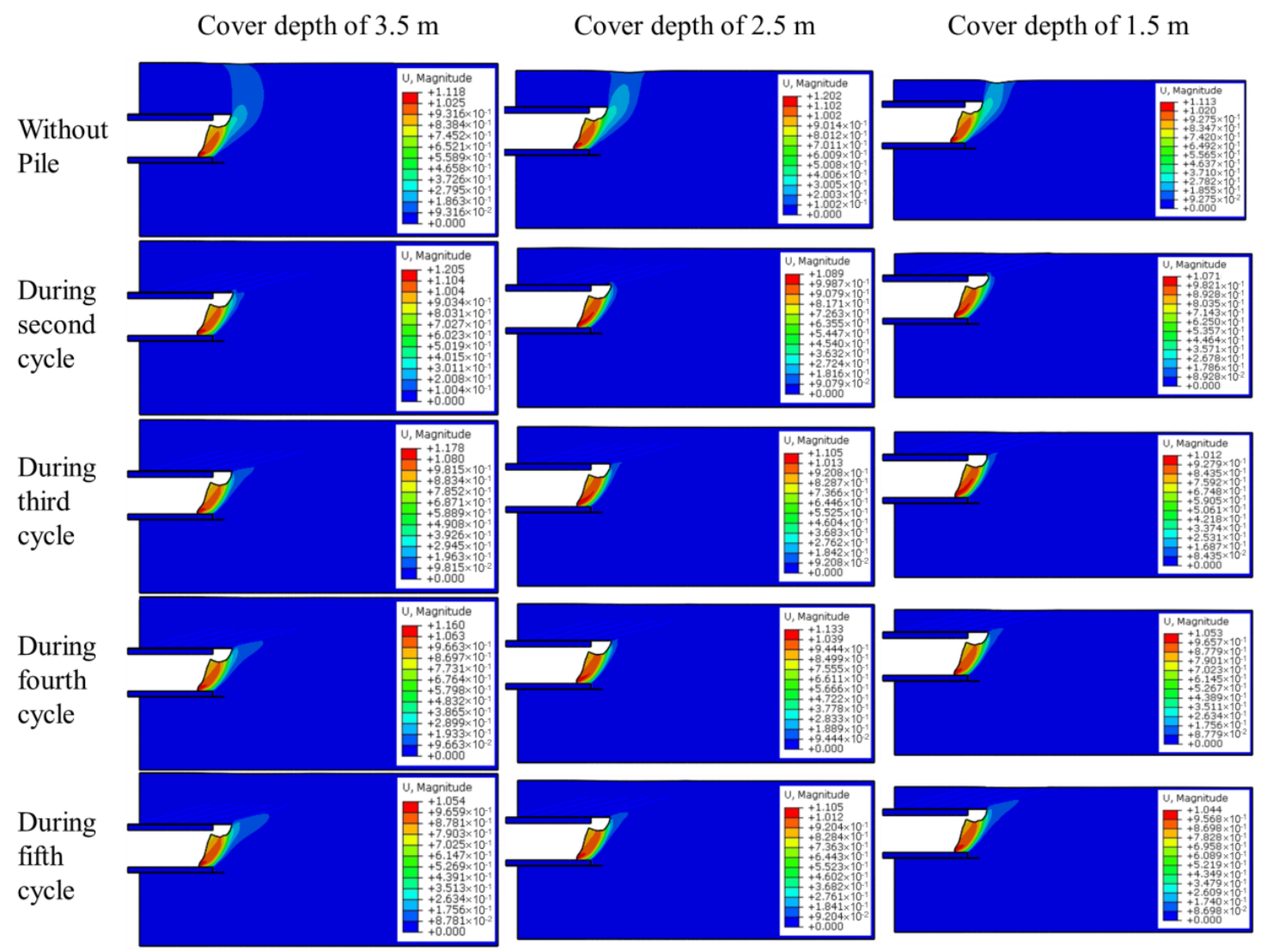

Figure 15. Ground displacement during Stage 1 of each construction cycle. 
When there was no pile, a larger amount of ground settlement was observed because the arching effect of the ground was as low as the cover depth (Figure 16). As the cover depth decreased, the ground settlement increased because of the lack of the arching effect of the ground. A ground settlement of $194 \mathrm{~mm}$ was measured when the pile was not installed; however, the ground settlement decreased to below $38.5 \mathrm{~mm}$ when the piles were installed at a cover depth of $1.5 \mathrm{~m}$. It was observed that the amount of ground settlement increased during the progress of the construction step (Figure 17). Because the length of the overlapping section of the installed piles is $1.373 \mathrm{~m}$, as listed in Table 5, a new pile would further be installed at the tunnel face between the fourth and fifth cycles. Thus, the amount of ground settlement was estimated to be between 31.7 and $38.5 \mathrm{~mm}$.

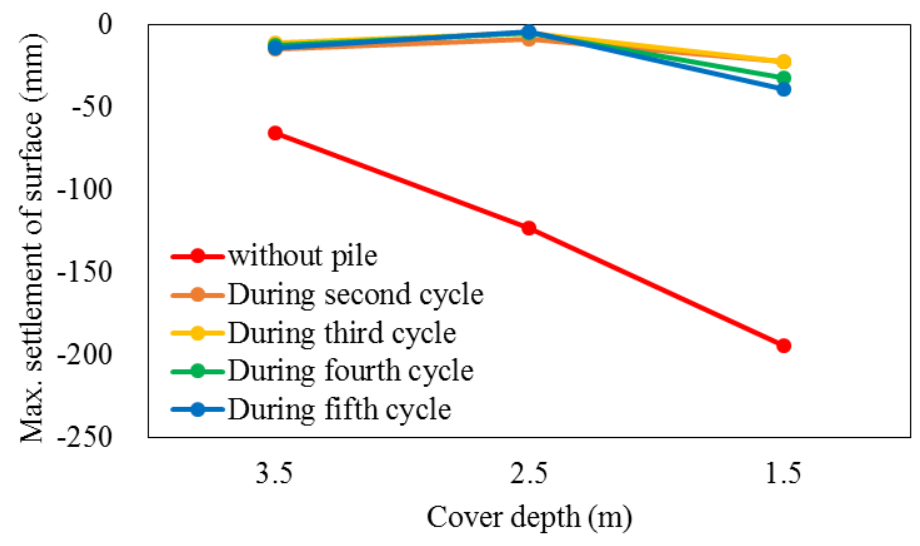

Figure 16. Displacement of ground surface during Stage 1 of each construction cycle based on cover depth.

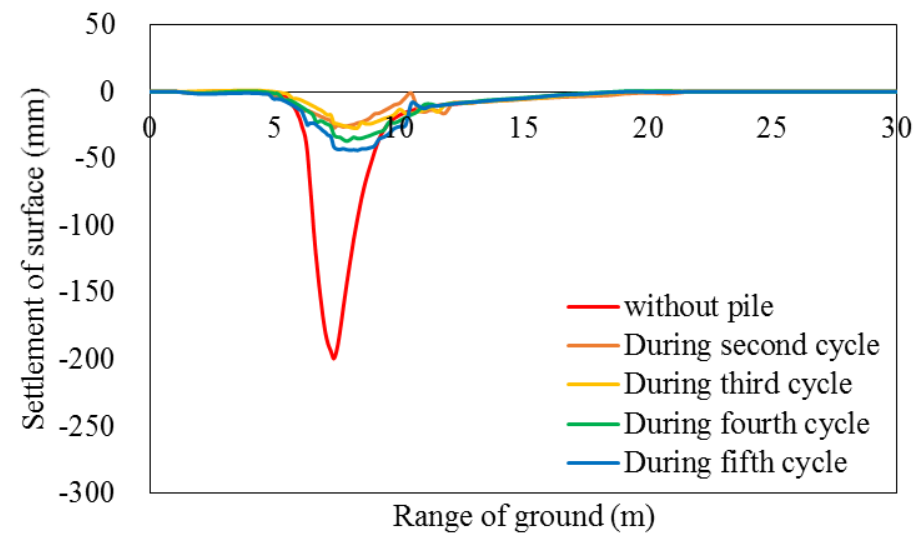

Figure 17. Surface settlement trough according to progress of construction step at cover depth of $1.5 \mathrm{~m}$.

The stresses acting on the piles during Stage 1 based on each cover depth and cycle are depicted in Figure 18. The stress contours in two or three nearest piles from the tunnel face were represented with blue color because these piles were bent downward, which helped to restrain the ground settlement. 


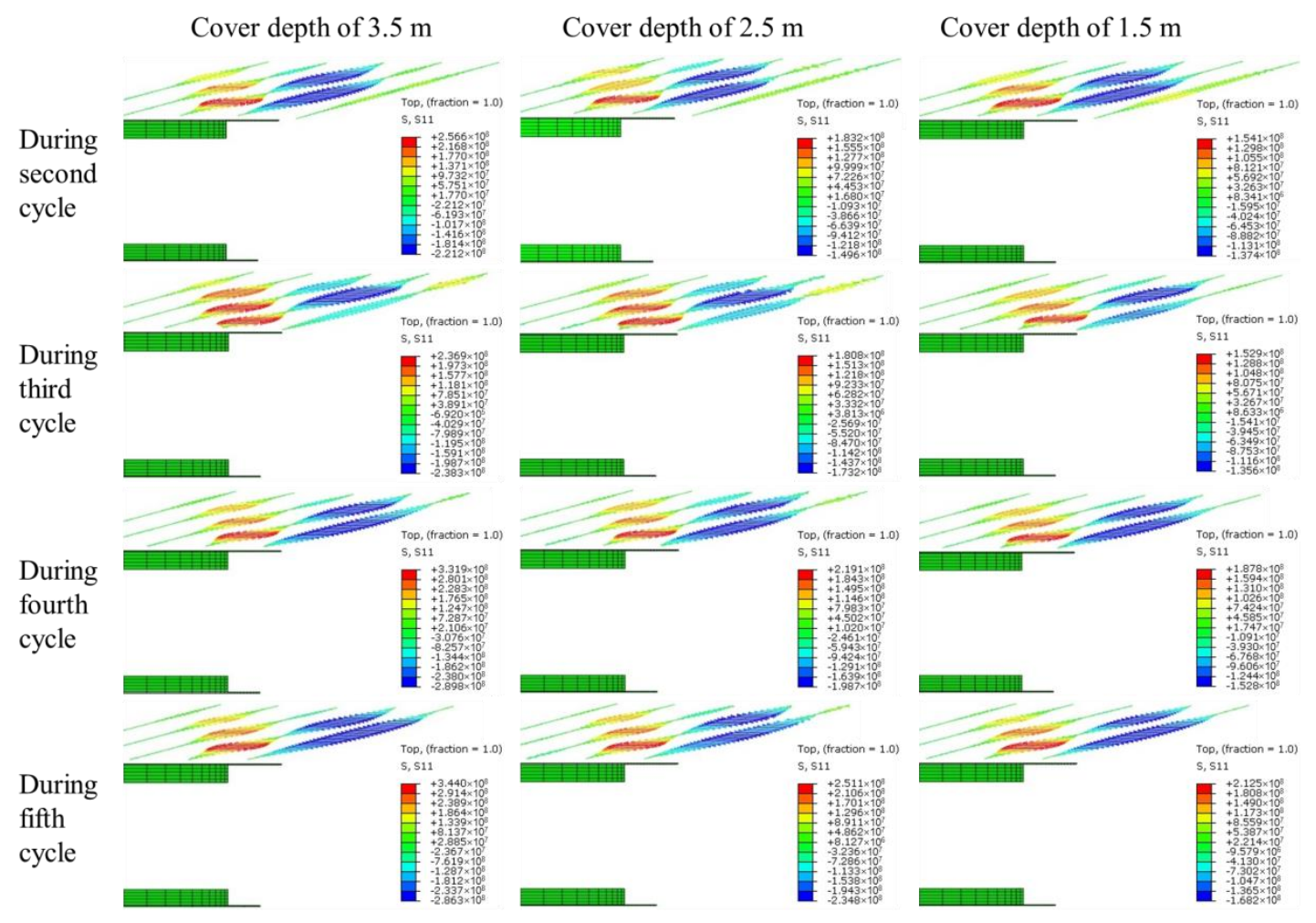

Figure 18. Stress acting on piles during Stage 1 of each construction cycle.

As the cover depth increased, the stresses acting on the piles increased as the ground load increased (Figure 19). By analyzing the stresses acting on the piles as the construction progressed, it was seen that they generally increased until the installation of the next pile. During the second cycle, Pile-1 could not help prevent the ground settlement well because it was located in front of the shoe structure. In addition, because the relative locations of the pile and shoe structure were varied based on the progress of the construction, it was observed that the point of maximum stress moved to the latter part of the pile during the third to fifth cycles (Figure 20). Considering the overlapping length of $1.373 \mathrm{~m}$ of the pile, as listed in Table 5, the stress acting on Pile- 1 was estimated to be between 152.83 (fourth cycle) and $168.19 \mathrm{MPa}$ (fifth cycle).

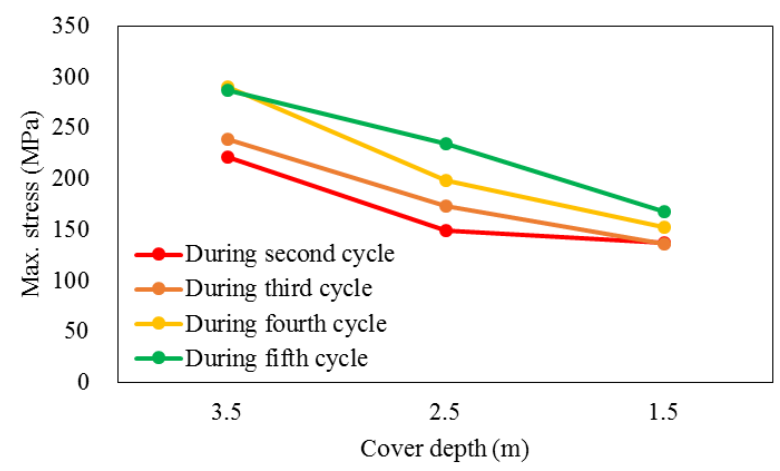

Figure 19. Maximum stresses acting on piles during Stage 1 of each construction cycle based on cover depth. 


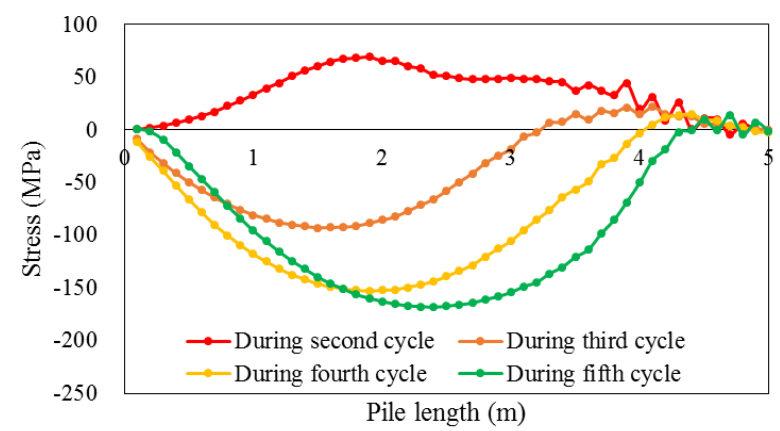

Figure 20. Variation in stress acting on Pile-1 during Stage 1 of each construction cycle at cover depth of $1.5 \mathrm{~m}$.

\subsection{Results of Numerical Analysis for Stage 2 of Each Construction Cycle}

The displacement of the ground occurred upwards from the tunnel face during Stage 2 of each construction cycle when there was no pile. However, when the piles were installed, it prevented the heave and dispersed the displacement of the ground forward. This tendency was observed particularly at low cover depths (Figure 21).

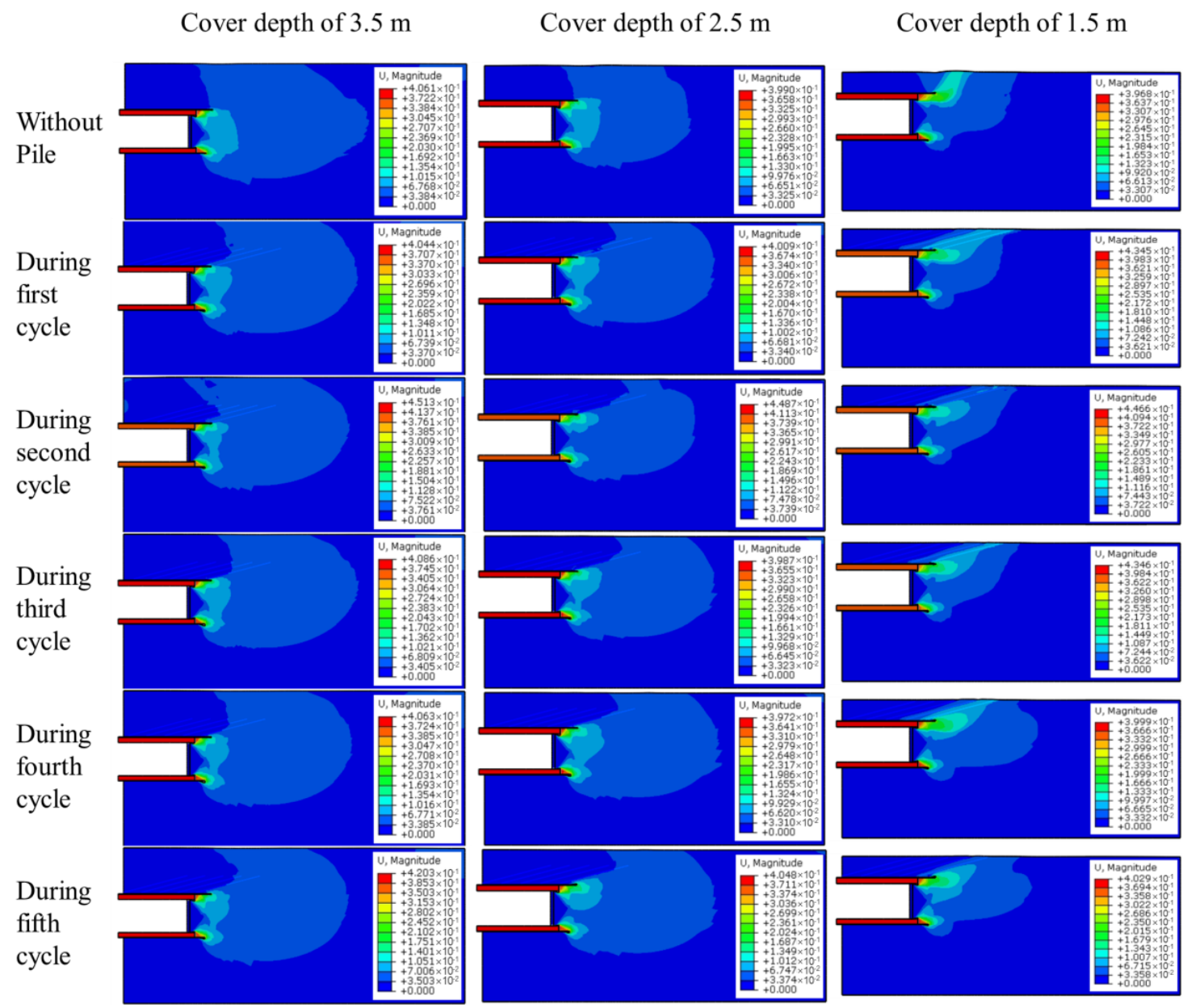

Figure 21. Ground displacement during Stage 2 of each construction cycle. 
In the presence as well as absence of piles, with a decrease in cover depth, the heave of the ground surface increased owing to the small overburden load, because the load counters the force of heave (Figure 22). The graph presented in Figure 23 depicts the heave of the ground surface according to the progress of the construction at a cover depth of $1.5 \mathrm{~m}$. A heave of $94.0 \mathrm{~mm}$ was measured in the absence of the piles, but it was minimized to below $53.3 \mathrm{~mm}$ when the piles were installed. No relation was seen between heave and the progress of construction. Thus, the largest amount of heave among all the cycles of pushing the precast structure, with the consideration of overlapping length, was estimated to be $53.3 \mathrm{~mm}$, which is the largest one among the results of the analysis.

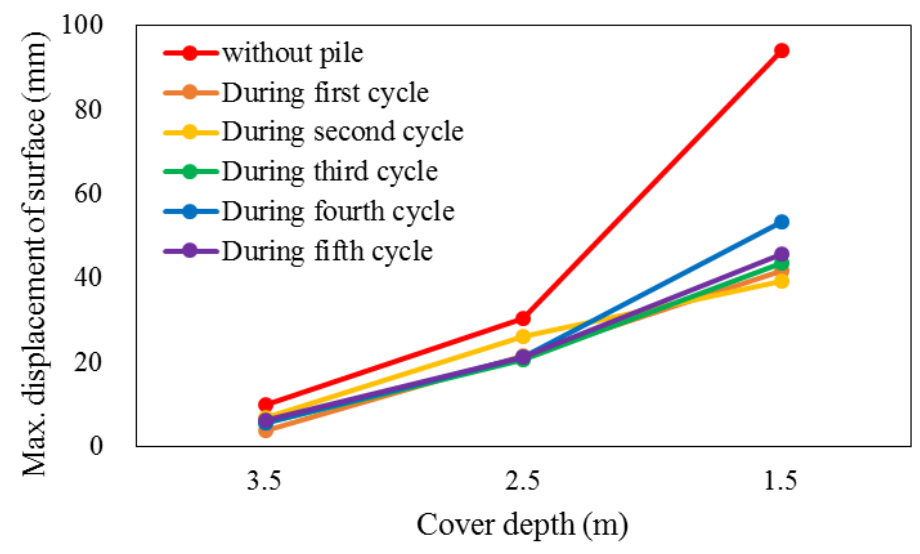

Figure 22. Displacement during Stage 2 of each construction cycle based on cover depth.

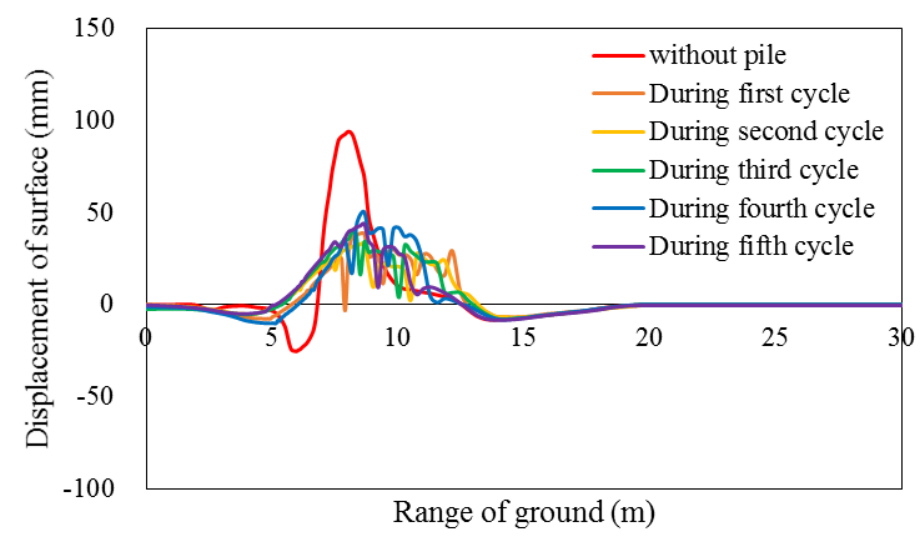

Figure 23. Surface heave trough according to progress of construction at cover depth of $1.5 \mathrm{~m}$.

The stresses acting on the piles when the precast structure is pushed, based on each cover depth and cycle, are illustrated in Figure 24. The piles were bent upwards, which helped to restrain the heave of the ground. 


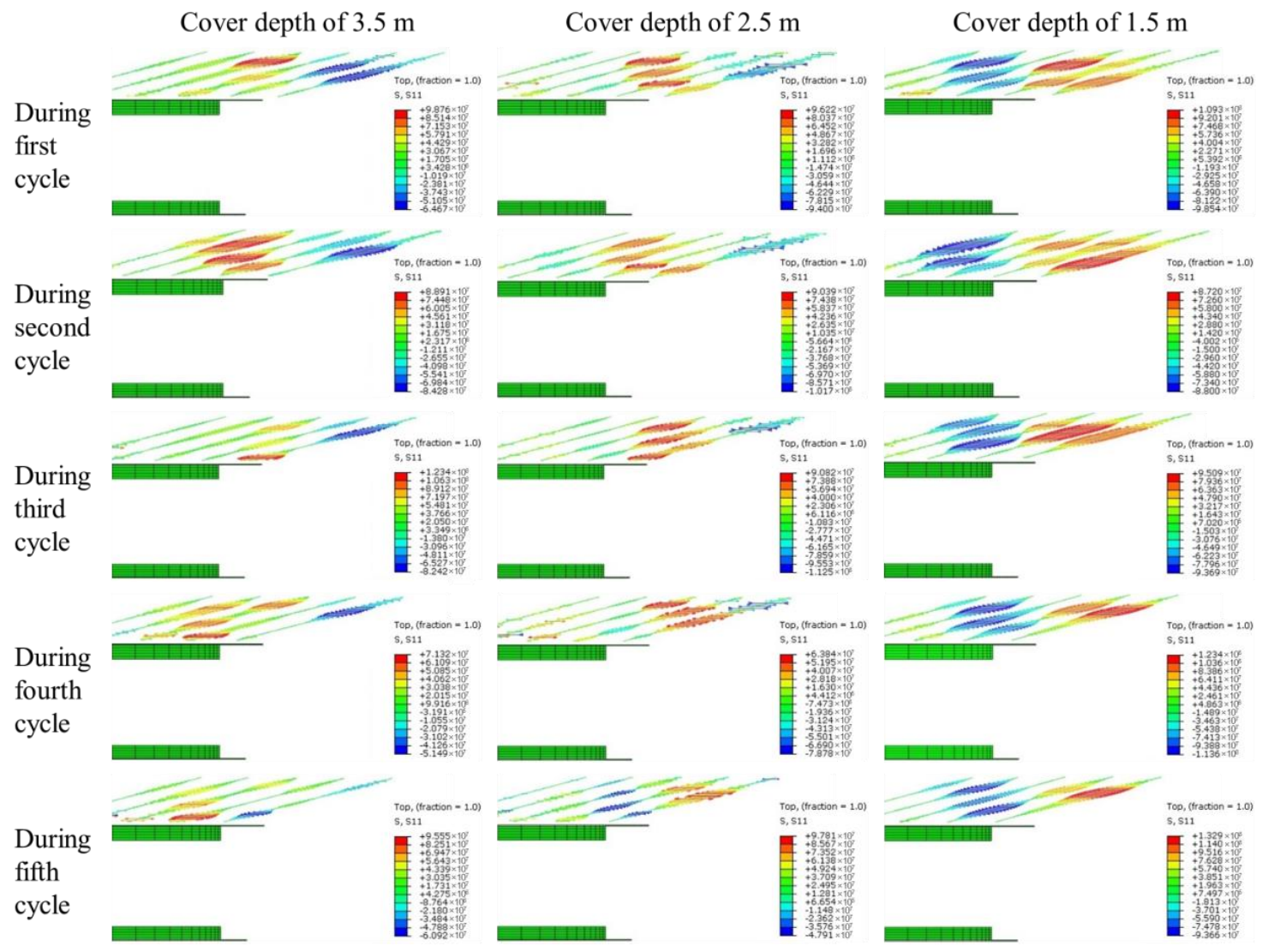

Figure 24. Stresses acting on piles during Stage 2 of each construction cycle.

As illustrated in Figure 24, the stress acting on a pile during the third cycle at a cover depth of $3.5 \mathrm{~m}$, which was a large tensile stress, was concentrated at the bottom of Pile-1. Owing to the bending of the pile, it had no connection with the stress acting on the pile. This occurred because the inserted shoe structure was close to the bottom point of the pile. Except for this case, the maximum stress acting on the piles was $85.2 \mathrm{MPa}$, which is an acceptable value for the tendency of the graph (Figure 25). As the cover depth decreased, the piles were bent more owing to the small overburden load, which counters the force of heave. Therefore, the stresses acting on the piles generally increased. However, no relation was identified between the stresses acting on the piles and the order of the cycle when the precast structure was pushed. The graph presented in Figure 26 displays the variation in stress acting on the pile at a cover depth of $1.5 \mathrm{~m}$ based on the progress of the construction. It was seen that, because the relative locations of the pile and shoe structure were varied based on the progress of the construction, the point of maximum stress moved to the latter part of the pile during the first to fifth cycles. Considering the overlapping length of the pile as listed in Table 5, the stress acting on Pile-1 was estimated to be between 123.4 (fourth cycle) and 132.9 MPa (fifth cycle).

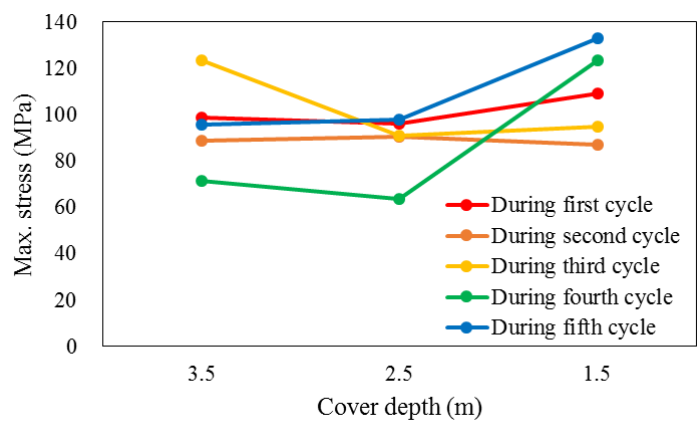

Figure 25. Maximum stress acting on pile during Stage 2 of each construction cycle based on cover depth. 


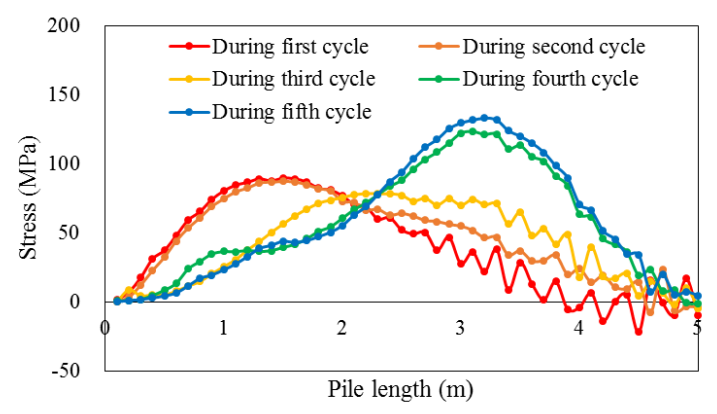

Figure 26. Variation in stress acting on Pile-1 during Stage 2 of each construction cycle at cover depth of $1.5 \mathrm{~m}$.

\section{Conclusions}

This study led to the following conclusions:

1. Whereas the tunnel face collapsed to the ground surface when the pressure panel was pulled back (Stage 1) in the absence of any pile, the settlement of the ground was restrained by approximately 83-97\% when the piles were installed because they prevented ground settlement. As the cover depth decreased, the ground settlement increased because of the lack of the arching effect of the ground. The displacement of the ground surface occurred upwards during the step of pushing the precast structure (Stage 2) when there was no pile. However, when the piles were installed, they prevented the heave and dispersed the displacement of the ground forward. The heave of the ground surface was restrained by approximately $14-43 \%$. These tendencies were observed particularly at low cover depths in all cases.

2. During Stage 1, as the cover depth increased, both the ground load and stress acting on the pile increased. During Stage 2, as the cover depth decreased, the overburden load, which counters the force of heave, was small and the piles were bent more. The stresses acting on the piles generally increased.

3. During Stage 1, if the height of the precast structure is greater at the same cover depth, the stresses acting on the piles are large owing to ground loss. However, in the case of Stage 2, the stresses acting on the piles are low because the lower precast structure was further away from the surface of the ground.

4. During Stage 1, the shoe structure was reduced by $33 \%$ of the stress acting on the piles. During Stage 2, the shoe structure was reduced by an average of $49 \%$ of the stresses acting on the piles using Jumunjin sand in model tests.

5. During Stage 1, at low cover depth, the amount of ground settlement and stress acting on the piles increased as the construction of the tunnel progressed. During Stage 2, no tendency of stresses acting on the piles according to the progress of the construction was seen.

Author Contributions: H.Y. supervised the research; J.K. proposed the concept of research and developed study; J.-j.K. and H.R. contributed to reviewing the final paper and made recommendations for paper revision. All authors have read and agreed to the published version of the manuscript.

Funding: This research was funded by Seoul Institute of Technology (SIT) (2020-AA-006, A study on the smart measurement management system and policies for securing safety of underground construction site).

Conflicts of Interest: The authors declare no conflict of interest. 


\section{References}

1. Choi, W.I. Stress Release Zone Characteristics and Reinforcement Around Sub-Structure Constructed by Non-open Cut Method Under Railway. Ph.D. Thesis, Department of Railway System, Seoul National University of Science and Technology, Seoul, Korea, 2016.

2. Dassault Systemes Simulia Corp. Abaqus/CAE User's Manual. 2016. Available online: http://130.149.89.49: 2080/v2016/books/usi/default.htm (accessed on 5 July 2015).

3. The Improvement of Management System of Crossing Road Construction in Non-Open-Cut Method; Korea Expressway Corporation (KEC): Gyeongsangbuk-do, Korea, 2012.

4. Kim, D.S.; Kim, J.B.; Lee, S.S.; Shim, J.W.; Shin, J.H.; Seo, H.S. A case study on the safety and measurement of non-open-cut underground roads. The Safety Technology. Korea Ind. Saf. Assoc. 2014, 201, 34-37. [CrossRef]

5. Eum, K.Y.; Shin, M.H.; Kim, J.H. The analysis of ground behavior on the crossing construction under railroad using field measurement. In Proceedings of the Korean Society for Railway, Suwon, Korea, 25-26 October 2001; pp. 546-551.

6. Shin, E.C.; Roh, J.M. Estimation of RPS method using three-dimensional numerical analysis. J. Korean Soc. Rail. 2006, 9, 174-179.

7. Eum, K.Y.; Kim, Y.H.; Park, Y.G.; Jeon, S.S. Displacement analysis in each excavation stage using field data obtained from measuring instrument Front-jacking method application. In Proceedings of the Korean Society for Railway, Busan, Korea, 18-20 May 2017; pp. 1145-1149.

8. Kim, H.G.; Park, E.H.; Cho, K.H. A study on the comparison by the methods of estimating the relaxation load of SEM-pile. J. Korean Tunn. Undergr. Sp. Assoc. 2018, 20, 543-560.

9. Shin, E.C.; Kim, J.H.; Lee, E.S.; Roh, J.M. Three-dimensional numerical analysis of crossing tunnel under railroad using RPS method. In Proceedings of the Korean Society for Railway, Uiwang, Korea, 19-20 May 2005; pp. 85-92.

10. Lee, Y.K.; Kim, S.K.; Kim, H.G. A Study on Seismic Performance Evaluation of the Buried Box Structures with Pipe Roof. In Proceedings of the Korean Society of Civil Engineers Convention, Gwangju, Korea, 24-26 October 2012; pp. 2315-2318.

11. Eum, K.Y.; Jeon, S.S.; Yun, J.H.; Park, S.K. Simulation of ground behavior induced by applying large diameter steel pipe jacking method. In Proceedings of the Korean Society for Railway, Busan, Korea, 18-20 May 2017; pp. 1133-1138.

12. Kim, H.K.; Choi, C.Y.; Kim, B.I. Optimum design section of non-open cut underpass construction method, super equilibrium method (SEM) by numerical analysis. J. Korean Soc. Urban. Rail. 2018, 6, 139-149. [CrossRef]

13. Kim, D.K. Proposal of Design Method for Umbrella Arch Method Used in NATM Tunnel. Master's Thesis, Pusan National University, Busan, Korea, 2004.

14. Petrova, R. Perusal of the Finite Element Method; Web of Science; InTech: Rijeka, Croatia, 2016.

(C) 2020 by the authors. Licensee MDPI, Basel, Switzerland. This article is an open access article distributed under the terms and conditions of the Creative Commons Attribution (CC BY) license (http://creativecommons.org/licenses/by/4.0/). 